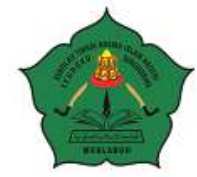

AT-TASYRI' Jurnal Ilmiah Prodi Muamalah

P-ISSN: 2085-2541, E-ISSN: 2715-7865

Volume 13, Nomor 2, Desember 2021

https://ejournal.staindirundeng.ac.id/index.php/Tasyri

\title{
KONSEP FILANTROPI ISLAM DI MASA PANDEMI COVID-19
}

\author{
Mellyan \\ Syariah dan Ekonomi Islam STAIN Teungku Dirundeng Meulaboh \\ mellyan@staindirundeng.ac.id* \\ Inayatillah \\ Syariah dan Ekonomi Islam STAIN Teungku Dirundeng Meulaboh \\ inayatillah@staindirundeng.ac.id
}

\begin{abstract}
Abstrak
Pandemi Covid-19 telah membawa perubahan perilaku kehidupan sosial. Penerapan protokol covid-19, persoalan kesehatan hingga kekacauan perekonomian melahirkan tatanan kehidupan baru bagi peradaban manusia. Di balik berbagai persoalan, pandemi Covid-19 juga menggugah empati, di masa sulit manusia saling membantu untuk bertahan hidup. Hal tersebut dikenal dengan istilah filantropi, yang dapat dimaknai sebagai voluntary action for the public good atau tindakan sukarela untuk kepentingan publik. Penelitian ini menggunakan metode kualitatif, Library Research (penelitian kepustakaan) dengan pendekatan analisis deskriptif. Adapun Rumusan Masalahnya adalah bagaimana konsep dan praktik filantropi Islam di masa Pandemi Covid-19 serta Bagaimana Filantropi dapat menjadi solusi ditengah pandemi Covid-19? Hasil penelitian menunjukkan, gerakan amal (a philanthropical movement) gencar digaungkan di tengah pandemi Covid-19. Hal tersebut sejalan dengan konsep filantropi Islam. Filantropi diwujudkan dalam bentuk memberi bantuan (harta, fasilitas) kepada pihak yang membutuhkan. Dalam Islam, Allah memerintahkan umatnya peduli dan berbagi. Perintah untuk peduli dan berbagi ini, direalisasikan dalam bentuk zakat, infak, sedekah, hibah, wasiat dan juga wakaf (ZISWAF). Majelis Ulama Indonesia (MUI) mengeluarkan Fatwa No 23 Tahun 2020 terkait pendayagunaan Zakat Infaq dan Shadaqah di masa pandemi Covid-19. Selain itu para publik figure, organisasi kemasyarakatan, dan tokoh publik menggunakan pengaruhnya untuk meningkatkan jumlah dana yang terkumpul. Terutama di era digital, media sosial berperan penting dalam jumlah perolehan pendanaan yang lebih besar. Jika sebelum pandemi, filantropi Islam secara umum dilaksanakan untuk meningkatkan kesejahteraan masyarakat. Maka di masa pandemi manfaat filantropi Islam langsung terfokus pada tujuan khusus, yaitu membantu masyarakat yang terdampak Pandemi Covid-19, seperti keluarga ekonomi lemah yang kehilangan pencari nafkah utama akibat Covid-19, memastikan ketersediaan Alat Pelindung Diri (APD) bagi tenaga medis dan sebagainya yang terkait langsung dengan Pandemi. Filantropi dapat menjadi jalan keluar sekaligus modal sosial dalam menghadapi pandemi Covid-19.
\end{abstract}

Kata Kunci: Filantropi. ZISWAF, Pandemi, Covid-19

\begin{abstract}
The Covid-19 pandemic has brought changes in the behavior of social life. The implementation of the Covid-19 protocol, health issues to economic chaos gave birth to a new life order for human civilization. Behind the various problems, the Covid-19 pandemic also inspires empathy, in difficult times humans help each other to survive. This is known as philanthropy, which can be interpreted as voluntary action for the public good. This study uses a qualitative method, Library Research (library research) with a descriptive analysis approach. The formulation of the problem is how are the concepts and practices of Islamic philanthropy during the Covid-19 pandemic and how can philanthropy be a solution in the midst of the Covid-19 pandemic? The results showed that a philanthropical movement was intensively echoed in the midst of the Covid-19 pandemic. This is in line with the concept of Islamic philanthropy. Philanthropy is manifested in the form of providing assistance (assets, facilities) to those in need. In Islam, Allah commands his people to care and share. This command to care and share is realized in the
\end{abstract}


form of zakat, infaq, alms, grants, wills and waqf (ZISWAF). The Indonesian Ulema Council (MUI) issued Fatwa No. 23/2020 regarding the utilization of Zakat, Infaq and Sadaqah during the Covid-19 pandemic. In addition, public figures, community organizations, and public figures use their influence to increase the amount of funds raised. Especially in the digital era, social media plays an important role in obtaining a larger amount of funding. Before the pandemic, Islamic philanthropy was generally carried out to improve people's welfare. During a pandemic, the benefits of Islamic philanthropy are immediately focused on specific goals, namely helping people affected by the Covid-19 Pandemic, such as economically weak families who have lost their main breadwinner due to Covid-19, ensuring the availability of Personal Protective Equipment (PPE) for medical personnel and so on. directly related to the Pandemic. Philanthropy can be a way out as well as social capital in dealing with the Covid-19 pandemic.

Keywords: Philanthropy. ZISWAF, Pandemic, Covid-19

\section{A. PENDAHULUAN}

Pandemi Corona Virus Disease-19 (Covid-19) telah melemahkan perekonomian dunia. Sebagaimana laporan Kementerian Keuangan Republik Indonesia, pada kuartal II-2020 pertumbuhan Produk Domestik Bruto (PDB) sebagian besar negara di dunia melambat. Pelemahan ekonomi domestik merupakan persoalan krusial dan patut diwaspadai. Optimalisasi penanganan Covid19 menjadi faktor utama penguatan perekonomian. Sampai akhir Mei 2020, realisasi pendapatan negara dan hibah telah mencapai $\mathrm{Rp}$ 664,32 triliun, namun capaian pendapatan negara dan hibah tersebut tumbuh negatif 9,02 persen (yoy) (Publikasi APBN KiTa (Kinerja dan Fakta, 2020). Covid-19 berimbas pada setiap sektor kehidupan. Tidak seperti krisis-krisis sebelumnya, yang melemahkan hanya dari sisi permintaan, namun juga sisi penawaran perekonomian. Sehingga tekanan terhadap pertumbuhan perekonomian dirasakan di banyak negara. Badan keuangan dunia memperkirakan pandemi Covid-19 akan menyebabkan kontraksi perekonomian dunia sebesar $-2,0 \%$ sampai $2,8 \%$ pada 2020 , dari sebelumnya tumbuh sebesar rata-rata $2,9 \%$ pada 2019 . Di waktu yang sama, pandemi Covid-19 diperkirakan juga akan mengurangi arus perdagangan dan investasi global hingga $30 \%$, serta menambah volatilitas pasar keuangan dunia hingga 215\%. Berkurang dengan drastisnya berbagai aktivitas perekonomian global diperkirakan akan mengakibatkan tidak kurang 195 juta orang akan kehilangan pekerjaan dan antara 420 sampai 580 juta orang jatuh pada jurang kemiskinan (Mohamad Ikhsan Modjo, 2020).

Di Indonesia sendiri, berdasarkan data Kementerian Ketenagakerjaan terhitung 20 April 2020 tercatat sebanyak 2.084.593 pekerja dari 116.370 perusahaan dirumahkan. Hal ini terjadi karena sejumlah perusahaan mengalami penurunan produksi bahkan berhenti berproduksi. Sektor Usaha Mikro Kecil dan Menengah atau UMKM yang selama ini terbukti mampu bertahan, bahkan ketika krisis 1998 UMKM dianggap paling mampu bertahan dan dapat mendorong perekonomian Indonesia. Menurut Menteri keuangan Indonesia Sri Mulyani Indrawati, sektor UMKM paling terpukul di tengah pandemi akibat dari pelarangan kegiatan di luar rumah. Perekonomian Indonesia juga diprediksi menurun. Sri Mulyani memperkirakan ekonomi nasional akan negatif 3,8\% pada kuartal II tahun 2020. Jika ditilik lebih lanjut, kemerosotan perekonomian yang hampir merata di setiap sektor disebabkan oleh ketidakpastian (uncertainty) dan berbagai risiko lainnya. Persoalan belum dilakukannya tes secara 
merata dan persoalan tidak semua masyarakat percaya dan memiliki kemauan untuk divaksin, merupakan penyebab adanya assymetric information, sehingga menyebabkan aktivitas sosial akan dibayangbayangi ketidakpastian dan tentu saja memiliki risiko yang cukup tinggi (Mohamad Ikhsan Modjo, 2020).

Tidak dapat dipungkiri, perekonomian merupakan salah satu bidang yang paling terdepresiasi karena pandemi Covid-19. Pemerintah, berdasarkan laporan Menteri Keuangan Republik Indonesia Realisasi Belanja Pemerintah Pusat hingga 31 Mei 2020 mencapai Rp537,3 triliun, lebih tinggi 1,2 persen dari realisasi APBN 2019. Peningkatan kinerja realisasi Belanja Pemerintah Pusat tersebut antara lain dipengaruhi oleh realisasi bantuan sosial yang mencapai Rp78,85 triliun atau tumbuh 30,71 persen (yoy). Pertumbuhan realisasi bantuan sosial di tahun 2020 dipengaruhi oleh penyaluran berbagai program Jaring Pengaman Sosial (JPS) yang dilakukan Pemerintah dalam menghadapi pandemi Covid-19. Sementara itu, berbagai belanja yang tidak terkait penanganan Covid-19 pada Kementerian/Lembaga (K/L) dilakukan penghematan ditunda pelaksanaannya. (Publikasi APBN KiTa (Kinerja dan Fakta, 2020). Bantuan tersebut disalurkan oleh Pemerintah untuk membantu perekonomian masyarakat terdampak pandemi Covid-19. Hal tersebut dilakukan untuk menjaga pemenuhan kebutuhan pokok dan menjaga daya beli masyarakat terutama kalangan ekonomi lemah. Selain pemerintah, sangat diharapkan masyarakat dapat ikut andil, meringankan beban sesama di masa-masa sulit seperti saat ini. Islam sebagai agama Rahmatan lil alamin, telah menganjurkan bahkan memerintahkan umatnya untuk membantu sesama. Salah satu ajaran Islam yang diperintahkan Allah kepada umatnya adalah peduli dan berbagi. Ajaran itu tak hanya menjadi sebuah kebaikan, tetapi melekat dalam salah satu rukun Islam, yang wajib untuk dilaksanakan. Perintah untuk peduli dan berbagi ini, diejawantahkan dalam bentuk zakat yang merupakan kewajiban bagi umat Islam dan infak, sedekah, serta wakaf yang tergolong kepedulian sosial yang disunnahkan dalam ajaran Islam.

Filantropi sering digunakan untuk sikap kepedulian terhadap sesama sebagaimana (Kasdi, 2016), mengartikannya dengan rasa kecintaan kepada manusia yang terpatri dalam bentuk pemberian derma kepada orang lain (Ilchman, 2006). Filantropi juga dimaknai sebagai konseptualisasi dari praktik pemberian sumbangan sukarela (voluntary giving), penyediaan layanan sukarela (voluntary services) dan asosiasi sukarela (voluntary association) secara suka rela untuk membantu pihak lain yang membutuhkan sebagai ekspresi rasa cinta. Berdasarkan definisi diatas menunjukan bahwa tradisi Islam melalui zakat, infak, sedekah dan wakaf dapat dimasukan dalam kategori praktik filantropi. Sesuatu yang memang secara teologis dan syariah memiliki landasan hukum yang kuat. (Jurnal Ekonomi Syariah, 2017).

Sebagai contoh salah satu praktik filantropi yang paling terkenal di Indonesia adalah Dompet Dhuafa yang memiliki tujuan mulia melalui berbagai programnya untuk mengentaskan kemiskinan. Dompet Dhuafa adalah lembaga nirlaba yang memiliki lima program utama, yaitu kontribusi terhadap pendidikan, kesehatan, ekonomi, sosial dan dakwah serta budaya. Penggalangan dana tersebut memberikan dampak luar biasa terhadap masyarakat. Sehingga pada 8 Oktober 2001 Kementerian Agama RI mengeluarkan Surat Keputusan Nomor 439 Tahun 2001 tentang Pengukuhan Dompet Dhuafa sebagai Badan Amil Zakat Nasional. 
Oleh karenanya artikel ini ditulis bertujuan untuk mendiskusikan konsep filantropi Islam di tengah pandemi Covid-19, serta menilik berbagai praktik-praktik baik yang dilakukan untuk membantu sesama di masa pandemi Covid-19 dan program serta solusi apa saja yang dapat ditawarkan melalui praktik filantropi Islam untuk membantu masyarakat terdampak pandemi Covid-19.

\section{B. KAJIAN TEORI}

\section{Konsep Filantropi}

Filantropi sering diartikan

kedermawanan. Kata filantropi berasal dari bahasa Yunani yang terdiri dari dua kata yaitu philos yang berarti cinta atau kasih dan anthropos yang berarti manusia. Jadi secara harfiah filantropi dapat diterjemahkan sebagai suatu kegiatan cinta kasih kepada sesama manusia, yang diwujudkan dalam bentuk memberi bantuan (harta, fasilitas) kepada pihak yang membutuhkan (Ahmad Gaus AF, 2008). Filantropi merupakan konseptualisasi dari praktek memberi (giving), pelayanan (services) dan asosiasi (association) secara sukarela untuk membantu orang/pihak lain yang membutuhkan sebagai ekspresi rasa cinta (Faozan Amar, 2017). Filantropi juga bisa dimaknai sebagai voluntary action for the public good atau tindakan sukarela untuk kepentingan publik. Filantropi sendiri hadir dari semangat untuk mendayagunakan dan menumbuhkan kemandirian civil society (Qi Mangku Bahjatulloh, 2016)

Filantropi dalam sejarah kelahirannya sampai dengan sekarang berkembang dalam dua bentuk besar yakni filantropi tradisional dan filantropi keadilan sosial. Filantropi tradisional adalah aktivitas yang berbasis charity (amal) dalam bentuk pemberian untuk kepentingan pelayanan sosial, misalkan pemberian langsung para dermawan untuk kalangan miskin dalam rangka memenuhi kebutuhan sehari-hari. Sementara itu filantropi keadilan sosial adalah mencari akar permasalahan dari kemiskinan yakni adanya faktor ketidakadilan dalam alokasi sumber daya dan akses kekuasaan dalam masyarakat. Sehingga dapat dimaknai bahwa filantropi bukanlah sekedar charity (amal), akan tetapi lebih pada pendampingan yang bersifat pemberdayaan dan berdampak jangka panjang. Selanjutnya konsep filantropi tidak hanya semata-mata bersinggungan dengan material saja, namun dipahami secara luas dengan memberikan waktu, uang dan pengetahuan bagaimana cara mengembangkan kebaikan bersama. Artinya keterlibatan secara luas seluruh aktifitas manusia dalam berbagai bidang dengan penuh kerelaan, partisipasi, dedikasi, gagasan, waktu luang, kontribusi materi merupakan bagian yang tidak dapat dipisahkan dari konsep filantropi (Qi Mangku Bahjatulloh, 2016)

Dorongan bagi aktivitas filantropi pada umumnya berasal dari agama. Semua agama mengajarkan pemeluknya untuk berderma, yakni mengeluarkan sebagian hartanya untuk orang lain yang kekurangan. Ajaran Hindu mendorong pemeluknya untuk berderma guna mewujudkan kesejahteraan masyarakat. Ajaran Budha juga menekankan pentingnya memberi kepada sesama agar tercipta keadilan sosial. Dalam agama Yahudi terdapat ajaran tentang sedekah. Begitu juga agama Kristen yang sangat kuat mengandung doktrin kasih sayang kepada sesama. Dengan demikian filantropi atau kedermawanan merupakan konsep universal, yang mengakar dalam tradisi agama-agama (Ahmad Gaus AF, 2008).

Sebagaimana agama-agama lain, agama Islam pun memiliki ajaran tentang filantropi. Bahkan ajaran filantropi dianggap sangat penting dalam Islam sehingga kewajiban mengeluarkan harta yang dikenal dengan istilah zakat menjadi Rukun Islam yang ketiga 
setelah syahadat dan shalat. Konsep filantropi dalam Islam telah ada sejak 15 abad yang lalu sejak zaman Nabi Muhammad SAW. Dimana perintah untuk membayar zakat, berinfak, sedekah, dan wakaf yang merupakan bagian dari filantropi telah ditetapkan sejak tahun kedua Hijriah. Pada masa sekarang wujud filantropi Islam digali dari doktrin keagamaan yang bersumber dari Al-Qur'an dan Hadis yang dimodifikasi dengan mekanisme ijtihad sehingga melahirkan institusi zakat, infaq, sedekah, dan wakaf yang bertujuan agar harta tersebut tidak hanya berputar pada orangorang kaya saja (QS. al-Hasyr: 7) tetapi perputaran uang dapat dirasakan oleh semua lapisan (Ahmad Gaus AF, 2008).

Dalam Islam, konsep filantropi telah dipraktikkan sejak sejak zaman Nabi Muhammad Saw. Hal ini karena perintah untuk berzakat, infak, sedekah, dan wakaf, yang merupakan bagian dari filantropi, telah turun sejak tahun kedua hijriyah. Yakni ketika Nabi hijrah dari Makkah ke Madinah. Ibnu Katsir, salah seorang ilmuan Muslim ternama mengemukakan, "Zakat ditetapkan di Madinah pada abad kedua hijriyah. Tampaknya, zakat yang ditetapkan di Madinah merupakan zakat dengan nilai dan jumlah kewajiban yang khusus sedangkan zakat yang ada sebelum periode ini, yang dibicarakan di Makkah, merupakan kewajiban perseorangan semata". Hal ini dipertegas oleh Yusuf Qardawi (1999), bahwa dalam sejarah perundang-undangan Islam, zakat baru diwajibkan di Madinah. Jika membedah sejarah, terdapat suatu kecendrungan di kalangan para penguasa Muslim mulai dari Daulah Abbasiyah sampai Turki Utsmani, mempraktikan filantropi dalam berbagai bentuk kelembagaan, khususnya dalam bidang pendidikan. Nizhamiyah yang didirikan pada abad ke 10 dan $11 \mathrm{M}$ di Baghdad, yang merupakan religious endowment (wakaf) dari penguasa ketika itu. Praktik zakat (almsgiving), sedekah (donation, giving) dan waqaf telah mengakar dalam tradisi masyarakat Islam dan memainkan peranan penting antara negara dan civil society (Faozan Amar, 2017).

Urgensi filantropi Islam dapat dilihat dari cara Al-Qur'an menekankan keseimbangan antara mengeluarkan zakat dan menegakkan shalat. Penegasan perintah mengeluarkan zakat disebutkan dalam AlQur'an sebanyak 72 kali dan menggandengkannya dengan perintah shalat. Kata infak dengan berbagai bentuk derivasinya muncul sebanyak 71 kali dan kata sedekah muncul sebanyak 24 kali. Hal ini menunjukkan pengamalan zakat dinilai setara dengan pelaksanaan ibadah shalat (Abdurrohman Kasdi, 2016).

Di antara ayat Al- Qur'an maupun Hadits yang dengan tegas memerintahkan untuk berderma, berbagi dan peduli kepada sesama umat manusia. QS, At-Taubah: ayat 103, yang artinya: "Ambillah zakat dari sebagian harta mereka. Dengan zakat itu, kamu membersihkan dan mensucikan mereka, dan berdoalah untuk merka. Sesungguhnya doamu itu (menjadi) ketenteraman jiwa bagi mereka. Dan, Allah Maha Mendengar lagi Maha Mengetahui. Dalam QS Adz Dzariyat ayat 19 disebutkan "Dan pada harta-harta mereka ada hak untuk orang miskin yang meminta dan orang miskin yang tidak mendapat bagian". Nabi Saw menegaskan: "Ada tiga hal yang aku bersumpah, maka hafalkanlah, yaitu tidak akan berkurang harta mereka karena bersedekah, tidak ada seorang hamba pun yang dizalimi kemudian ia bersabar, pasti Allah akan menambahkan kemuliaan, dan tidak ada seorang hamba pun yang membuka pintu meminta-minta, kecuali Allah akan membukakan baginya pintu kefakiran." (HR. At-Tirmidzi). Dari ayat dan hadis tersebut Allah memerintahkan umatnya untuk mengeluarkan zakat yang 
didalamnya mengandung hikmah ketentraman jiwa, karena di dalam harta tersebut terdapat hak para fakir miskin. Perintah berbagi dan peduli kepada sesama begitu banyak ditemui baik dalam Alquran maupun hadis.

Berdasarkan Al-Qur'an dan Hadis, filantropi Islam dapat diklasifikasikan dalam beberapa bentuk filantropi sebagai berikut:

\section{Zakat}

Zakat secara etimologi mempunyai beberapa pengertian antara lain, yaitu keberkahan, pertumbuhan dan perkembangan, kesucian, dan keberesan. Ibadah ini dinamakan zakat karena dapat mengembangkan dan mensucikan serta menjauhkan harta dari bahaya manakala telah dikeluarkan zakatnya. Sedangkan secara terminologis, zakat adalah mengeluarkan sebagian harta yang telah memenuhi syarat tertentu kepada yang berhak menerimanya dengan syarat-syarat tertentu pula. sehingga harta yang sudah dikeluarkan zakatnya akan menjadi harta yang bersih, suci, berkah, dan lebih berkembang (Abdiansyah Linge, 2016). 2. Infak

Istilah infak berasal dari bahasa Arab yaitu anfaqa - yanfiqu - infaaqan yang bermakna mengeluarkan atau membelanjakan harta. Infaq dapat didefinisikan memberikan sesuatu kepada orang lain untuk suatu kepentingan yang diperintahkan oleh ajaran agama Islam. Infaq merupakan pemberian dimana jumlah yang dikeluarkan tidak ditentukan oleh Allah dan tergantung pada tingkat kemampuan seseorang (Abdiansyah Linge, 2016).

\section{Sedekah}

Sedekah berasal dari kata bahasa Arab yaitu shadaqah yang berarti suatu pemberian yang diberikan oleh seseorang muslim kepada orang lain secara spontan dan sukarela tanpa dibatasi oleh waktu dan jumlah tertentu. Juga berarti suatu pemberian yang diberikan oleh seseorang sebagai kebajikan yang mengharap ridha Allah SWT dan pahala semata (Anang Wahyu Eko, 2017).

4. Wakaf

Istilah wakaf merupakan bentuk masdar dari kata kerja waqafa - yaqifu, yang berarti melindungi dan menahan. Wakaf adalah instrumen filantropi Islam yang mendasarkan fungsinya pada unsur kebajikan dan persaudaraan. Ciri utama wakaf yang sangat membedakan adalah ketika wakaf ditunaikan terjadi pergeseran kepemilikan pribadi menuju kepemilikan Allah SWT yang diharapkan abadi, memberikan manfaat secara berkelanjutan. Melalui wakaf diharapkan akan terjadi proses distribusi manfaat bagi masyarakat secara luas, dari manfaat pribadi (private benefit) menuju manfaat masyarakat (social benefit).

Kesediaan umat untuk mewakafkan hartanya didasari keimanan dan ketaatan kepada Allah SWT. Menurut pandangan Islam, wakaf didasari landasan hukum yang tercantum di dalam Al-Qur'an dan Hadis yang berbicara tentang kebaikan. Al-Quran tidak membicarakan secara langsung tentang wakaf sehingga ibadah wakaf ini masuk dalam kajian fikih (Anang Wahyu Eko, 2017).

Sejak tahun 1970-an telah muncul lembaga-lembaga filantropi Islam modern yang berbasis kelembagaan dengan pengelolaan zakat, infak, dan sedekah secara profesional. Berbeda dengan charity tradisional yang memberikan zakat, infak, dan sedekah secara langsung kepada penerima atau mustahik, filantropi modern mengelola dana zakat, infak, dan sedekah untuk disalurkan bagi usaha-usaha produktif dan berkelanjutan. Bentuknya berupa pinjaman modal usaha bagi pengusaha kecil, pemberian beasiswa pendidikan bagi anakanak kurang mampu, pendirian balai kesehatan untuk masyarakat tidak mampu, 
dan usaha lain yang menunjang. Pada intinya konsep filantropi di era modern adalah "memberikan kail dan bukan ikan". Tujuannya agar pihak penerima bisa diberdayakan secara ekonomi, sehingga nantinya mereka mampu mandiri. Bahkan mereka akan menjadi muzakki atau pihak pemberi dana filantropi bagi kelompok masyarakat lain yang membutuhkan atau belum terberdayakan secara ekonomi (Ahmad Gaus AF, 2008).

Di antara lembaga-lembaga filantropi Islam modern adalah: Badan Amil Zakat, Infak, dan Sedekah (BAZIS), Yayasan Dompet Dhuafa, Pos Keadilan Peduli Umat (PKPU), Yayasan Dana Sosial Al-Falah di Surabaya, Yayasan Daarut Tauhid di Bandung, dan Yayasan Amil Zakat di Lampung, badan-badan pengumpul zakat milik organisasi massa Islam seperti Muhammadiyah dan NU, Baitul Mal wa Tanwil yang berbasis di masjid-masjid, lembaga-lembaga pengumpul dan penyalur ZIS di perusahaan-perusahaan, dan lain-lain (Ahmad Gaus AF, 2008).

Bahkan dalam catatan sejarah menunjukkan ketika masa resesi ekonomi Hindia Belanda mencatat, filantropi menyelamatkan banyak jiwa. Organisasi yang berdiri pada September 1935 ini Bernama Komite Umum Bantuan Kaum Miskin (Algemeene Armenscommissie). Mereka memberikan bantuan kepada orang-orang yang berhak dan memenuhi kriteria tertentu berupa makanan, uang tunai hingga tempat tinggal gratis. Di Bangka Belitung para buruh timah, baik pribumi maupun Eropa mengadakan penggalangan dana dengan menggelar berbagai pertunjukan dan hiburan. Kemudian bantuan diberikan kepada mereka yang berhak menerimanya (Historia.id). Terlihat jelas Filantropi memegang peranan penting dalam perekonomian, terutama di masa krisis.

\section{METODE PENELITIAN}

Penelitian ini menggunakan metode kualitatif dengan pendekatan deskriptif analisis. Pendekatan deskriptif mencoba menjelaskan fenomena-fenomena sosial yang diteliti berupa kondisi, situasi yang berlangsung dalam hubungan sosial. Tujuan dari pendekatan deskriptif adalah memberikan gambaran secara menyeluruh dan mendalam mengenai fenomena yang diteliti, yang kemudian dianalisis dan diinterpretasikan. Rumusan masalah pada penelitian ini adalah bagaimana konsep dan praktik filantropi Islam di masa Pandemi Covid-19?, Bagaimana Filantropi dapat menjadi solusi ditengah pandemi Covid-19? Adapun tujuan penelitian adalah untuk mengetahui konsep dan praktik filantropi Islam di masa Pandemi Covid-19. Pada kajian ini difokuskan menganalisis dan mengkaji fenomena sosial terkait penggalangan dana yang dilakukan oleh berbagai pihak, termasuk masyarakat dan influencer untuk meringankan beban di masa Pandemi Covid19 melalui media sosial maupun platform online lainnya. Sehingga diharapkan dapat menghasilkan pemahaman komprehensif mengenai hal tersebut (Ardial, 2014). Dalam temuan penelitian, penulis akan mengolah semua temuan penelitian dalam bentuk deskriptif. Penulisan hasil penelitian kualitatif dengan cara deskriptif sesuai dengan penjabaran untuk analisa fenomena sosial, terutama untuk penelitian yang mengkaji teks berita atau artikel. Adapun tujuannya untuk mengembangkan konsep yang sudah ada dan mengumpulkan fakta-fakta (Atwar Bajari, 2015). Di samping itu, penulis menganalisis bagaimana filantropi berjalan dalam kondisi pandemi Covid-19.

\section{HASIL DAN PEMBAHASAN}

\section{Praktik Filantropi Islam di Tengah Pandemi Covid-19}


Gerakan amal (a philanthropical movement) gencar digaungkan di tengah pandemi Covid-19. Hal tersebut karena dampak lain yang ditimbulkan oleh virus Corona selain persoalan kesehatan adalah semakin terpuruknya perekonomian. Dan yang paling mengerikan bukan hanya kematian karena virus itu sendiri, melainkan kelaparan, kemiskinan bahkan kematian akibat dari berkurangnya pendapatan dan semakin sulitnya bekerja di tengah pandemi Covid-19. Berbagai persoalan yang tidak pernah diprediksi, terjadi dengan cepat sehingga menimbulkan kepanikan di tengah masyarakat. Kepanikan yang sangat jelas terlihat adalah masyarakat berduyun-duyun mendatangi pusat perbelanjaan untuk membeli berbagai kebutuhan pokok dan bahan serta peralatan yang dapat digunakan untuk mencegah terjadinya penyebaran virus Covid-19. Sehingga di tengah ketakutan penularan virus, masyarakat harus menghadapi minimnya persediaan masker dan handsanitizer. Meskipun di beberapa tempat tersedia, harganya melonjak beberapa kali lipat.

Fenomena panic buying dapat terjadi ketika konsumen membeli sejumlah besar produk untuk mengantisipasi, atau setelah bencana atau untuk mengantisipasi kenaikan atau kekurangan harga yang besar. Panic buying sering dikaitkan dengan keserakahan dapat dikontraskan dengan panic selling yang dikaitkan dengan ketakutan, hal tersebut menjadi penyebabnya kelangkaan barang yang tersedia di pasar. Mereka yang memiliki daya beli yang baik, membeli persediaan secara berlebihan sehingga menimbulkan kelangkaan di pasar.

Pandemi covid-19 telah mengakibatkan pertumbuhan negatif ekonomi Indonesia. Dari rilis pertumbuhan ekonomi Indonesia pada triwulan 1-2020 yang dikeluarkan oleh
Badan Pusat Statistik (BPS) menunjukkan Angka pertumbuhan Produk Domestik Bruto (PDB) Indonesia pada triwulan-1 2020 tercatat hanya sebesar 2,97\% (year-on-year) yang merupakan angka pertumbuhan terendah sejak 2001. Angka ini juga jauh lebih rendah dari prediksi Kementerian Keuangan dan Bank Indonesia, yang sebelumnya masih memperkirakan pertumbuhan di kisaran 4\%-5\% pada triwulan-1 2020. (Mohamad Ikhsan Modjo, 2020).

Sri Mulyani, Menteri Keuangan Republik Indonesia dalam laporannya menyatakan hampir seluruh jenis pajak utama terkontraksi di Januari hingga Mei 2020 karena kontraksi penerimaan di Mei yang cukup dalam akibat perlambatan kegiatan ekonomi sebagai dampak Covid-19 dan pemanfaatan insentif fiskal dalam rangka pemulihan ekonomi nasional. Sementara itu, penerimaan seluruh sektor usaha di Januari hingga Mei 2020 tumbuh negatif. Ini berkebalikan dengan Januari-April 2020 di mana Industri Pengolahan dan Jasa Keuangan dan Asuransi masih tumbuh positif. Kegiatan produksi melambat akibat terbatasnya suplai bahan baku impor dan pembatasan kegiatan produksi akibat Covid-19. Volume penjualan barang dan jasa pada berbagai sektor juga sangat tertekan akibat PSBB, menurunnya daya beli, serta perubahan pola spendingsaving masyarakat dalam menghadapi pandemi.

Demikian pula dengan PDB negaranegara di dunia yang mengalami efek negatif dari Covid-19, dimana jumlah pengangguran yang semakin meningkat, harga komoditas yang semakin merosot dan berbagai persoalan lainnya. Untuk mengatasi persoalan tersebut, masyarakat bersama dengan pemerintah untuk membantu sesama di saat-saat sulit. Pentingnya kedermawanan sebagai modal sosial dalam menanggulangi dampak dari 
pandemi Covid-19. Masyarakat dengan perekonomian menengah ke bawah adalah bagian yang paling merasakan dampak dari pandemi. Filantropi dapat dijadikan jalan keluar sekaligus modal sosial bagi masyarakat dalam menghadapi pandemi ini. Berbagai pihak melakukan berbagai aksi sosial untuk membantu saudara yang terkena dampak pandemi. Aksi penggalangan dana semakin banyak dilakukan di tengah kemerosotan ekonomi dan ancaman pandemi Covid 19.

Donasi dari Dompet Dhuafa juga menggerakkan berbagai program untuk membantu masyarakat di tengah Covid-19, antara lain program Pembagian sembako untuk masyarakat miskin dhuafa dan pekerja jalanan terdampak Covid-19, Pembagian APD untuk tenaga medis, Pelatihan pemulasaran jenazah Covid-19 untuk tenaga medis, Mobile Health Services: layanan medis door to door untuk kaum dhuafa dan berbagai program bermanfaat lainnya. Kemudian program bersatu hadang Corona yang digagas oleh Lazismu juga membantu meringankan beban bersama.

Secara mandiri, para pemuda mudamudi Desa Somongari, Kecamatan Kaligesing,Kabupaten Purworejo berinisiatif untuk mengadakan penggalangan dana secara mandiri guna membantu masyarakat yang terdampak wabah virus Corona. Dari kegiatan tersebut terkumpul dana sebesar Rp. 25 juta dan telah disalurkan kepada 107 masyarakat terdampak Covid-19 (jateng.suara.com, 2020). Sementara itu, Kitabisa telah mengumpulkan dana sebesar Rp. 116 miliar donasi terkait covid-19 yang berasal dari 715 ribu donatur. Dana tersebut nantinya akan dibagi ke dalam tiga kategori, yaitu program pengadaan alat perlindungan diri (APD) bagi tenaga medis, pembagian makanan langsung dan dapur umum, serta gerakan penyediaan sembako bagi masyarakat yang membutuhkan (https://republika.co.id, 2020). Bakulan Medan telah membuka donasi paket THR dan sembako yang disalurkan ke tiga titik, yaitu Medan, Sibolga, dan Meulaboh, Aceh Barat. Total donasi 100 Bakul Kebaikan terkumpul Rp. 4.900.000., dan telah disalurkan pada 19 Mei 2020. Kemudian sedekah parcel untuk anak yatim dan kaum dhuafa yang digagas oleh Basajan.Net dan telah membagikan 50 parcel bagi yang membutuhkan pada 21 Mei 2020 (basajan.net, 2020). Chief Executive Officer (CEO) Kitabisa, Alfatih menyatakan dalam kondisi seperti ini, rasa kemanusiaan diuji. Kepedulian memuncak, solidaritas dan gotong-royong bertambah. Terbukti dengan peningkatan jumlah donasi secara signifikan selama pandemi. Kegiatan donasi dan amal tersebut juga selaras dengan konsep filantropi Islam yang dapat diidentifikasi sebagai sedekah (donation giving). Di tengah pandemi masyarakat telah membuktikan kepedulian terhadap sesama atas dasar kemanusiaan dan anjuran agama.

Pandemi Covid-19 selain memberikan efek negatif, juga membangkitkan solidaritas untuk membantu sesama. Masyarakat kelas menengah ke bawah merupakan golongan pertama yang merasakan efek pandemi Covid-19, terutama di bidang perekonomian. Meskipun, tidak dapat dipungkiri semua pihak merasakan efek dari wabah tersebut. Namun di masa-masa sulit, keinginan untuk meringankan beban sesama juga tumbuh dengan baik.

Seperti Yasasan Graisena, yang merupakan kumpulan anak muda yang mencoba membantu keluarga ekonomi lemah yang kehilangan pencari nafkah utama akibat virus corona, karena banyak warga yang terjangkit virus sehingga mereka kehilangan tulang punggung untuk menghidupi keluarga, baik yang diisolasi di rumah sakit, isolasi mandiri maupun meninggal dunia. Graisena, 
selama 14 hari memberikan bantuan sebesar Rp 20.000,- kepada setiap anggota keluarga dengan pasien. Jika secara medis sang pencari nafkah harus melanjutkan karantina di rumah sakit lebih dari dua pekan, mereka akan meneruskan bantuan dana tersebut, maksimal hingga hari ke-45, (BBC.Com, 2020). Solidaritas serupa kini juga terus muncul di berbagai media sosial. Seperti situs penggalangan dana berbasis publik, Kitabisa.com, hingga pertengahan Maret 2020 telah menggerakan pengumpulan bantuan bertajuk \#BersamaLawanCorona, hingga terkumpul Rp. 2 miliar hingga Maret 2020. Sumbangan tersebut digunakan antara lain untuk membeli alat pelindung diri bagi petugas medis dan peralatan disenfektan. Keluarga para pekerja informal seperti ojek online juga menjadi salah satu sasaran penerima donasi (BBC.Com, 2020). Kemudian juga terdapat gerakan sosial pekerja BRI Grup "BRILian Fight Covid-19" 62.000 pekerja BRI Grup telah menghimpun dana bantuan sukarela sebanyak Rp. 22.16 miliar, (Katadata.Id, 2020). Kitabisa.com melalui platformnya telah menerima dana Rp. 118.9 miliar dari 714.591 donatur (Tri Kurnia Yunianto, Katadata.id, 2020).

Melalui program \#BagiAsa, selain sembako juga memberikan makanan siap saji yang disiapkan Accelerice. Sampai Mei 2020, donasi publik yang terkumpul sudah berjumlah $\mathrm{Rp}$ 917.302.883 dan akan dibagikan bantuan sosial dalam bentuk sembako, makanan, serta alat pelindung diri (APD). (Muhammad Ahsan Ridhoi, katadata,id, 2020). Gerakan Indonesia Pasti Bisa yang didukung oleh donatur seperti perusahaan modal ventura East Ventures,
Tokopedia, hingga CEO Bytedance Zhang Yiming berhasil menggalang dana hingga $\mathrm{Rp}$ 10 miliar. Dana akan digunakan untuk pengembangan alat tes covid-19. Total sudah ada lebih dari 2.000 individu dan korporasi, baik dari dalam maupun luar negeri ikut berpartisipasi sebagai donatur (Fahmi Ahmad Burhan, Katadata.id, 2020). Selain itu, Total donasi yang masuk ke rekening Gugus Tugas Percepatan Penanganan Covid-19 hingga Mei 2020 mencapai lebih dari Rp. 72.2 miliar," (Dimas Jarot Bayu, Katadata.id, 2020).

Lembaga The Center for Asian Philanthropy and Society (CAPS) merilis survei kedua Doing Good Index (DGI2020) atau Indeks Berbuat Baik yang mengungkapkan peran vital dari sektor sosial. Studi yang dilakukan bekerja sama dengan CCPHI mengidentifikasi bagaimana donasi yang dilakukan oleh swasta/perusahaan maupun pemerintah dapat memenuhi kebutuhan masyarkat (Gatra.com, 2020). Di masa pandemi Covid-19, dengan dukungan pemerintah, nasional maupun internasional filantropi Asia dapat menyumbangkan setara $2 \%$ dari produk domestik bruto, maka diperkirakan terkumpul sebesar US\$ 587 miliar setiap tahunnya. Jumlah tersebut 12 kali lipat dari jumlah bantuan bersih luar negeri yang mengalir ke Asia, dan hampir $40 \%$ dari tambahan US\$ 1,5 triliun yang dibutuhkan Asia Pasifik setiap tahunnya guna memenuhi tujuan pembangunan berkelanjutan PBB pada 2030 (Gatra.com, Andika Dinata, 2020). Dompet Dhuafa telah menyalurkan bantuan sebesar Rp 22.729.263.777 di tahun 2020 dan menjadi 11 respon layanan besar secara nasional khusus untuk pandemi Covid-19.

Tabel 1. Realisasi Dana Penyaluran Program Covid-19 BAZNAS RI

\begin{tabular}{|c|l|c|}
\hline No & \multicolumn{1}{|c|}{ Bidang Program } & Zakat \\
\hline $\mathbf{1}$ & Darurat Kesehatan & \\
\hline & a.Promkes (Edukasi PHBS, Penyemprotan Disinfektan, dll) & 268.777 .411 \\
\hline & b.Kuratif (APD Nakes, Ruang Isolasi RSB, dll) & 1.823 .852 .122 \\
\hline
\end{tabular}




\begin{tabular}{|c|l|r|}
\hline No & \multicolumn{1}{|c|}{ Bidang Program } & \multicolumn{1}{c|}{ Zakat } \\
\hline $\mathbf{2}$ & Darurat Sosial Ekonomi & \\
\hline & a. Paket Logistik Keluarga & 933.710 .000 \\
\hline & b. Cash for Work & 170.868 .000 \\
\hline & c. Zakat Fitrah & 3.830 .125 .000 \\
\hline & d. BTM & 70.200 .000 \\
\hline $\mathbf{3}$ & Pengamanan Program Eksisting & 480.928 .530 \\
\hline & Total & $\mathbf{7 . 5 7 8 . 4 6 1 . 0 6 3}$ \\
\hline
\end{tabular}

Sumber: Denas Hasman Nugraha, Jurnal Ulubana, 2 Mei 2021

Dari tabel tersebut, dapat dilihat jika Baznas telah mendistribusikan dana zakat ke berbagai kebutuhan selam pandemi Covid-19. Di antaranya Darurat Kesehatan dengan dana total yang di keluarkan adalah Rp. 2.092.629.533, Kedua sektor darurat sosial ekonomi dengan dana total yang di keluarkan adalah Rp. 5.004.903.000, dan yang ketiga adalah sektor Pengamanan Program.

Eksisting untuk sektor ini BAZNAS menyalurkan dana sebesar Rp. 480.928.530. Total penyaluran dana ketiga sektor tersebut mencapai Rp. 7.578.461.063. Filantropi Islam telah mengambil perannya selama pandemi. Terbukti dengan lahirnya fatwa Majeli Ulama Indonesia (MUI) Nomor 23 Tahun 2020 terkait pendayagunaan Zakat, Infaq dan Shadaqah di masa Pandemi Covid-19. Fatwa tersebut dikeluarkan untuk membantu persoalan yang sedang dihadapi umat untuk mencegah, menangani dan menganggulangi persoalan yang ditimbulkan Pandemi Covid19, baik di bidang ekonomi, sosial maupun Kesehatan.

Zakat merupakan simbol ketataan hamba yang bersifat personal dan berhubungan dengan ketataan kepada sang pencipta. Dikutip dari (covid19.go.id/p) Sekretaris Komisi Majelis Ulama Indonesia (MUI), Asrorun Ni'am Sholeh, mengatakan bahwa zakat dapat dimanfaatkan untuk penanggulangan Covid-19 berdasarkan ketentuan tertentu. Hal tersebut dikarenakan salah satu lini kehidupan yang berdampak paling serius adalah bidang Kesehatan dan ekonomi.

Metode pendistribusian zakat di masa pandemi sebenarnya tidak banyak berbeda dengan sebelum pandemi. Jika zakat tersebut didistribusikan untuk kepentingan penerima secara langsung, penerima zakat tetap merupakan 8 asnaf sesuai ketentuan alquran. Distribusi zakat dapat disalurkan untuk kepentingan modal kerja, makanan pokok, pengobatan, uang tunai ataupun sesuatu yang paling dibutuhkan mustahik. Zakat juga dapat dimanfaatkan sebagai zakat produktif, untuk menstimulasi kegiatan ekonomi fakir miskin yang terkena dampak pandemi. Menurut Asrorun, dana zakat juga dapat dimanfaatkan untuk kemaslahatan umat dalam bentuk layanan kemaslahatan masyarakat, khususnya bagi mustahik zakat, seperti penyediaan Alat Pelindung Diri (APD) untuk tenaga medis, desinfektan, pengobatan, serta mengakomodir kebutuhan relawan. Dengan zakat, dapat memperbaiki daya konsumsi, produksi dan distribusi di kalangan masyarakat, sehingga dapat berdampak positif terhadap perekonomian.

Semangat membantu sesama di masa pandemi seperti yang ditunjukkan oleh berbagai kalangan di atas merupakan bukti dari rasa kemanusiaan yang tidak padam bahkan di saat sulit. Hal tersebut sesuai dengan semangat filantropi itu sendiri, yang merupakan konseptualisasi dari praktek memberi (giving), pelayanan (services) dan asosiasi (association) secara sukarela untuk 
membantu orang/pihak lain yang membutuhkan sebagai ekspresi rasa cinta (Faozan Amar, 2017). Filantropi juga bisa dimaknai sebagai voluntary action for the public good atau tindakan sukarela untuk kepentingan publik. Filantropi hadir dari semangat untuk mendayagunakan dan menumbuhkan kemandirian civil society. Filantropi dalam tradisi Islam melalui zakat, infak, sedekah, dan wakaf dapat membawa wacana kedermawanan Islam ke dalam sebuah diskursus yang dapat menjangkau isuisu yang lebih luas. Tidak hanya melihat masalahnya dari segi wacana tradisional saja, seperti fikih dan akhlak, melainkan juga dapat mengkaitkan dengan isu-isu keadilan sosial, kesejahteraan umat, masyarakat madani, kebijakan publik, tata kelola yang baik dan manajemen yang professional (Abdurrohman Kasdi, 2016).

Jika charity tradisional yang memberikan zakat, infak, dan sedekah secara langsung kepada penerima atau mustahik, filantropi modern mengelola dana zakat, infak, dan sedekah untuk disalurkan bagi usaha-usaha produktif dan berkelanjutan. Maka filantropi di masa pandemi menjadi berbeda, selain karena metode pengumpulan yang dilakukan oleh beragam latar belakang, termasuk donasi yang dilakukan oleh para Selebgram, artis, dan berbagai lembaga lainnya melalui sistem online, penerima manfaat juga terkait langsung dengan korban pandemi covid-19. Dari berbagai donasi atau filantropi yang melibatkan banyak pihak tersebut, dapat dirangkum dalam tabel berikut ini:

Tabel 1.2 Perbedaan Filantropi sebelum Covid dan di masa COVID-19

\begin{tabular}{|l|l|}
\hline \multicolumn{2}{|c|}{ Filantropi Islam (ZISWAF) } \\
\hline Sebelum Pandemi Covid-19 & \multicolumn{1}{c|}{ Masa Pandemi Covid-19 } \\
\hline $\begin{array}{l}\text { Meningkatkan kesejahteraan } \\
\text { masyarakat }\end{array}$ & $\begin{array}{l}\text { Membantu masyarakat ekonomi lemah yang terdampak Pandemi } \\
\text { Covid-19 }\end{array}$ \\
\hline Mengurangi angka kemiskinan & $\begin{array}{l}\text { Membantu keluarga ekonomi lemah yang kehilangan pencari } \\
\text { nafkah utama akibat virus corona }\end{array}$ \\
\hline Menghindari kemudharatan & $\begin{array}{l}\text { Untuk membeli alat pelindung diri (APD) bagi petugas medis dan } \\
\text { peralatan disenfektan }\end{array}$ \\
\hline & $\begin{array}{l}\text { Bantuan sosial dalam bentuk sembako, makanan siap saji untuk } \\
\text { warga terdampak pandemi }\end{array}$ \\
\hline Bantuan untuk membeli alat tes Covid-19, desinfektan \\
\hline & $\begin{array}{l}\text { Menjadi salah satu andalan dalam mengatasi krisis ekonomi } \\
\text { terkait pandemi Covid-19. } \\
\text { Penyaluran zakat produktif membantu fakir miskin yang } \\
\text { terdampak wabah pandemi Covid-19 }\end{array}$ \\
\hline Menyediakan layanan online terkait persoalan covid-19 \\
\hline
\end{tabular}

Dari berbagai sumber dan dianalisis oleh penulis

Jika dilihat dari tabel di atas, dapat diamati bahwa terdapat perbedaan pemanfaatan dari filantropi Islam sebelum masa pandemi covid-19 dibandingkan masa pandemi Covid-19. Jika sebelum pandemi, filantropi Islam secara umum dilaksanakan untuk meningkatkan kesejahteraan masyarakat, mengurangi kemudharatan, kehilangan pencari nafkah utama akibat virus menurunkan angka kemiskinan, serta meringankan beban sesama, maka di masa pandemi manfaat filantropi Islam langsung terfokus pada tujuan khusus, yaitu membantu masyarakat ekonomi lemah yang terdampak Pandemi Covid-19. Seperti membantu keluarga ekonomi menengah ke bawah yang 
corona, baik isolasi di rumah sakit maupun isolasi mandiri, bahkan meninggal dunia, membantu petugas medis yang berjuang di garda terdepan di masa pandemi, agar lebih terlindungi dengan menggalang dana untuk membeli alat pelindung diri (APD) bagi petugas medis dan peralatan disenfektan, serta membeli alat tes Covid-19.

Bantuan di masa pandemi juga fokus pada pemberian bantuan sosial dalam bentuk sembako, makanan untuk warga terdampak pandemi. Melalui filantropi diharapkan dapat menjadi salah satu andalan dalam mengatasi krisis ekonomi terkait pandemi Covid-19. Dari berbagai semangat filantropi, diharapkan pemerintah, organisasi kemasyarakatan serta masyarakat itu sendiri dapat bersinergi untuk bersama-sama meningkatkan filantropi Islam, yang kemudian dikelola secara serius untuk membantu perekonomian, terutama di masa pandemi Covid-19. Di antaranya, dengan membentuk organisasi/gugus Filantropi khusus Covid-19 yang dikoordinir oleh pemerintah dan dapat dijalankan bersama masyarakat. sehingga program filantropi dapat fokus membantu berbagai persoalan di masa pandemi Covid-19. Di antaranya untuk:

1. Membantu mengedukasi masyarakat mengenai perilaku hidup sehat serta pentingnya menaati Protokol Kesehatan (Prokes);

2. Meminimalisir berkembangnya pemberitaan hoax mengenai Pandemi di tengah Masyarakat;

3. Layanan bantuan pangan, vitamin dan logistik lainnya bagi masyarakat ekonomi lemah dan penyintas Covid-19;

4. Layanan Ambulance siaga dan penyemprotan desinfektan;

5. Hotline gratis bagi masyarakat untuk meminimalisir timbulnya kepanikan;

6. Alat Pelindung Diri (APD) Bagi Tenaga Kesehatan (Nakes), makanan dan vitamin untuk Nakes, dan lain sebagainya yang dapat berkembang disesuaikan dengan kebutuhan di masa pandemi.

\section{E. KESIMPULAN}

Konsep membantu sesama dari hasil penelitian ini dapat dilihat sejalan dengan semangat filantropi itu sendiri, yang merupakan konseptualisasi dari praktek memberi (giving), pelayanan (services) dan asosiasi (association) secara sukarela untuk membantu pihaklain. Di masa dunia terguncang dengan munculnya virus baru yang ditemukan di Wuhan, China penghujung tahun 2019 lalu, ternyata rasa kemanusiaan untuk meringankan beban sesama tumbuh dengan baik. Terbukti dari berbagai pihak, termasuk pemerintah, organisasi masyarakat, hingga individu, hingga artis dan selebgram saling membuka donasi untuk membantu pihak-pihak yang terkena dampak pandemi Covid-19, terutama untuk membantu masyarakat menengah ke bawah yang menjadi pihak paling awal yang merasakan efek pandemi, terutama di bidang ekonomi. Praktik filantropi di masa pandemi dapat diamati bahwa terdapat perbedaan pemanfaatan dari filantropi Islam sebelum masa pandemi covid-19 dibandingkan masa pandemi Covid-19. Jika sebelum pandemi, filantropi Islam secara umum dilaksanakan untuk meningkatkan kesejahteraan masyarakat, mengurangi kemudharatan, menurunkan angka kemiskinan, serta meringankan beban sesama, maka di masa pandemi manfaat filantropi Islam langsung terfokus pada tujuan khusus, yaitu membantu masyarakat ekonomi lemah yang terdampak Pandemi Covid-19, seperti membantu keluarga ekonomi menengah ke bawah yang kehilangan pencari nafkah utama akibat virus corona, baik isolasi di rumah sakit maupun isolasi mandiri, bahkan meninggal dunia, membantu petugas medis yang berjuang di 
garda terdepan di masa pandemi untuk membeli alat pelindung diri (APD) bagi petugas medis dan peralatan disenfektan, serta membeli alat tes Covid-19, bantuan di masa pandemi juga fokus pada pemberian bantuan sosial dalam bentuk sembako, makanan untuk warga terdampak pandemi. Bantuan tersebut terutama digalang melalui media sosial dan platform online lainnya.

\section{DAFTAR PUSTAKA}

Al-Quranul Karim

Abu Bakar, Irfan dan Chaidar S. Bamualim (ed.). (2006). Filantropi Islam dan Keadilan Sosial: Studi tentang Potensi, Tradisi, dan Pemanfaatan Filantropi Islam di Indonesia, kerjasama The Ford Foundation dan CSRC.

Abdurrohman Kasdi, (2016). Filantropi Islam untuk Pemberdayaan Umat, Igtishadia, Vol. 9. No. 2, (227-245).

Abdiansyah Linge, (2015). "Filantropi Islam sebagai Instrumen Keadilan Ekonomi”, Jurnal Perspektif Ekonomi Darussalam, Vol. 1, No. 2.

Al-Makassari, Ridwan. (2006). Pengarusutamaan Filantropi Islam untuk Keadilan Sosial di Indonesia; Proyek yang Belum Selesai: Jurnal Galang, 1(3), April.

Ahmad Gaus AF, (2008). Filantropi dalam Masyarakat Islam, (Elex Media Komputindo)

Anang Wahyu Eko, (2017). "Filantropi Islam sebagai stabilitas kehidupan", Transformasi: Jurnal Studi Agama Islam, Vol. 10, No. 1.

Ardial, (2014). Paradigma dan Model Penelitian Komunikasi, (Jakarta: Bumi Aksara).

Atwar Bajari, (2015). Metode Penelitian Komunikasi; Prosedur, Tren, dan Etika, (Bandung: Simbioasa Media Rekatama)

Chusnun Jusuf (2007), Filantropi Modern Untuk Pembangunan Sosial, Jurnal
Penelitian dan Pengembangan Kesejahteraan Sosial, (Vol 22 No 1)

Denas Hasman Nugraha (2021), Analisis Peran Zakat Pada Masa Pandemi Covid19, Jurnal Manajemen Dakwah, Qulubana, (Vol. 1 No.2)

Faozan Amar, (2017). "Implementasi Filantropi Islam di Indonesia", $A L$ URBAN: Jurnal Ekonomi Syariah dan Filantropi Islam, (Vol. 1, No. 1). https://www.bbc.com/indonesia/indonesia https://katadata.co.id/timpublikasikatadata/fi nansial/5ec11288383f9/62-ribukaryawan-bri-grup-bantu-masyarakatterdampak-covid-19

https://katadata.co.id/agustiyanti/berita/5e9a $41 \mathrm{f6e} 42 \mathrm{~d} 7 /$ masyarakat-ramai-donasiuntuk-corona-berapa-yang-terkumpul

https://katadata.co.id/muhammadridhoi/berit a/5ebb51c2a421b/perjuanganfoodbank-entaskan-kelaparan-wargarentan-saat-corona

https://nasional.kompas.com/read/2020/12/3 1/19384621/tingkat-penyaluranefektif-dompet-dhuafa-raih-acr-zakatcore-principle?page $=$ all

https://katadata.co.id/agustiyanti/digital/5ea7 b4e01791a/indonesia-pasti-bisagalang-rp-10-m-untuk-produksi-alattes-covid-19

https://katadata.co.id/yuliawati/berita/5eaa13 68ecf96/semangat-gotong-royongindonesia-meningkat-di-masapandemi-corona

https://historia.id/ekonomi/articles/filantropimasa-resesi-ekonomi-di-hindiabelanda-PK18y/page/4

https://donasi.dompetdhuafa.org/?gclid, diakses Juni 2021

https://covid19filantropi.id/4-peluangfilantropis-mengurangi-dampakwabah-covid-19/

https://www.worldometers.info/coronavirus/ , diakses pada 29 Juni 2020

https://jateng.suara.com/read/2020/05/22/215 815/kelompok-pemuda-sumongarigalang-dana-mandiri-antisipasi-efekcovid-19

https://republika.co.id/berita/q9jqys463/dona si-covid19-emkitabisacomem- 
terhimpun-rp-116-miliar, diakses pada 29 Juni 2020

https://basajan.net/secuil-senyum-untukyatim-dan-dhuafa/ diakses pada 29 Juni 2020

https://donasi.dompetdhuafa.org/bersamalaw ancorona/, diakses pada 29 Juni 2020

https://covid19.go.id/p/berita/muipemanfaatan-zakat-untukpenanggulangan-covid-19diperbolehkan, diakses pada 2 Desember 2021

http://s2es.uin.arraniry.ac.id/index.php/id/pos ts/peranan-zakat-dalam-menanganicovid-19, diakses 2 Desember 2021

Ilchman, Warren F., Stanley N. Katz, dan Edward L. Queen II (ed.). (2006). Philanthropy in the World Traditions (Filantropi di Berbagai Tradisi Dunia), Jakarta: Center for the Study of Religion and Culture (CSRC),

Jurnal Ekonomi Syariah dan Filantropi Islam Vol. 1, No. 1, Juni 2017 http://journal.uhamka.ac.id/index.php/a l-urban.

Kementerian Keuangan menerbitkan publikasi APBN KiTa (Kinerja dan Fakta) edisi Juni 2020 (http://kemenkeu.go.id/apbnkita)

Mohamad Ikhsan Modjo, (2020). Jurnal Memetakan Jalan Penguatan Ekonomi Pasca Pandemi, Binus University Indonesia.

Qardhawi, Yusuf. (1999). Fiqih Zakat: Dirasah Muqaranah li Ahkamiha wa Falsafatiha -Quran wa Sunnah, Beirut Libanon -Risalah, cet 24

Qi Mangku Bahjatulloh, (2016). "Pengembangan Pemberdayaan Ekonomi Masyarakat Melalui Kegiatan Filantropi, INFERENSI: Jurnal Penelitian Sosial Keagamaan, Vol. 10, No. 2.

Wibowo Hadiwardoyo, Kerugian Ekonomi Nasional Akibat PSBB, (Jurnal: Of Business and Entrepreneurship 2, No 2, 2020) 